\title{
Re-assessment of the type collections of Maslov's species of Hapalidiales (Rhodophyta). Species originally attributed to Lithothamnium, Mesophyllum and Palaeothamnium
}

\author{
Juan C. BRAGA ${ }^{1 *}$, Davide BASSI ${ }^{2}$, Julio AGUIRRE ${ }^{1}$, Elena ZAKREVSKAYA ${ }^{3}$ \& Éleonora \\ P. RADIONOVA
}

\author{
${ }^{1}$ Departamento de Estratigrafía y Paleontología, Universidad de Granada, Campus de Fuentenueva, E-18002 Granada, Spain; \\ jbraga@ugr.es; jaguirre@ugr.es \\ ${ }^{2}$ Dipartimento di Fisica e Scienze della Terra, Università di Ferrara, via Saragat 1, I-44122 Ferrara, Italy; bsd@unife.it \\ ${ }^{3}$ Vernadsky State Geological Museum RAS, Mokhovaya st. 11, bl. 2, 103009 Moscow, Russia; zey@sgm.ru \\ ${ }^{4}$ Geological Institute of Russian, Academy of Sciences, Pyzherskii pcr. 7, 109017 Moscow, Russia; radionova@geo.tv-sign.ru \\ * Corresponding author
}

Braga, J.C., Bassi, D., Aguirre, J., Zakrevskaya, E. \& Radionova, E.P. 2015. Re-assessment of the type collections of Maslov's species of Hapalidiales (Rhodophyta). Species originally attributed to Lithothamnium, Mesophyllum and Palaeothamnium. [Reevaluación de las colecciones tipo de especies de Hapalidiales (Rhodophyta) de Maslov. Especies atribuidas originalmente a Lithothamnium, Mesophyllum y Palaeothamnium]. Spanish Journal of Palaeontology, 30 (2), 189-208.

\section{ABSTRACT}

This is the third and last paper of a series devoted to the revision of the types of the species and infra-specific taxa of coralline red algae established in two monographs by Maslov (1956a, 1962). Maslov was a Russian palaeontologist who described many taxa of fossil calcareous algae from the former USSR from 1929 to 1973. As in other publications from those decades, Maslov's new species and infraspecific taxa were separated by characters of questionable significance from a modern taxonomic point of view. In this study, as in previous contributions, a number of types of fossil coralline algae in Maslov's original collection are re-assessed with a modern morpho-anatomic taxonomic approach. The collection consists of thin sections currently housed in the Geological Institute of the Russian Academy of Sciences of Moscow. This paper deals in particular with the types of species attributed by Maslov to the genera Lithothamnion

\section{RESUMEN}

Este es el tercer y último artículo de una serie dedicada a la revisión de los tipos de especies y taxones infra-específicos de algas coralinas establecidos por Maslov (1956a, 1962) en dos monografías. Maslov fue un paleontólogo ruso que describió muchos taxones de algas calcáreas fósiles de la antigua Unión Soviética entre 1929 y 1973 . Como en otras publicaciones de esa época, Maslov separó las nuevas especies y taxones infraespecíficos con caracteres diagnósticos cuestionables desde la perspectiva de la taxonomía moderna de las algas coralinas. En este trabajo, como en los dos anteriores, se revisan tipos de la colección original de Maslov, que consiste en láminas delgadas depositadas en el Instituto Geológico de la Academia de Ciencias de Rusia en Moscú. En particular, este artículo trata de las especies atribuidas por Maslov (1956a, 1962) a los géneros Lithothamnion (= Lithothamnium), Mesophyllum y Palaeothamnium (Hapalidiales, Rhodophyta). Sólo el 
(as Lithothamnium), Mesophyllum and Palaeothamnium (Hapalidiales, Rhodophyta). According to our reassessment, only the type of Mesophyllum schenckii var. corticesum (as Mesophyllum schenkii var. corticesum) can be confidently assigned to a currently accepted genus within the family Hapalidiaceae, subfamily Melobesioideae. The types of Lithothamnion iorii, Palaeothamnium kossovense, Mesophyllum kutense, Lithothamnion microcellulosum, Lithothamnion praefructiculosum, and Lithothamnion tchernomoricum possess multiporate conceptacles and non-coaxial ventral core and can be attributed to the subfamily Melobesioideae. The lack of epithallial cells, however, prevents any precise generic assignment within the Lithothamnion, Phymatolithon, Clathromorphum and Synarthrophyton complex. Finally, the lack of significant characters prevents any confident attribution of the type of 'Lithothamnion saxorum var. korolukae' to any defined generic or suprageneric taxon within the Hapalidiales or the Corallinales. The absence of reproductive structures in the types of 'Lithothamnion caucasicum', 'Lithothamnion (?) intergeminum', and 'Lithothamnion (?) suhumii' prevents the placement of these taxa in any order and family within Hapalidiales, Corallinales or Sporolithales.

Keywords: Calcareous algae, taxonomy, Melobesioideae, Hapalidiales, Rhodophyta. tipo de Mesophyllum schenckii var. corticesum (como Mesophyllum schenkii var. corticesum) puede ser asignado con certidumbre a un género actualmente aceptado dentro de la familia Hapalidiaceae, subfamilia Melobesioideae. Los tipos de Lithothamnion iorii, Palaeothamnium kossovense, Mesophyllum kutense, Lithothamnion microcellulosum, Lithothamnion praefructiculosum y Lithothamnion tchernomoricum presentan conceptáculos multiporados y región ventral no coaxial y pueden ser incluídos dentro de la subfamilia Melobesioideae. No obstante, la ausencia de células epiteliales impide una adscripción genérica precisa dentro del complejo Lithothamnion, Phymatolithon, Clathromorphum y Synarthrophyton. La imposibilidad de observar la naturaleza de los conceptáculos impide una asignación precisa del tipo de 'Lithothamnion saxorum var. korolukae' a una familia o subfamilia dentro de Hapalidiales o Corallinales. Finalmente, la ausencia de caracteres relevantes impide atribuir los tipos de 'Lithothamnion caucasicum', 'Lithothamnion (?) intergeminum', y 'Lithothamnion (?) suhumii' a ningún taxón genérico o supragenérico dentro de las Hapalidiales, Corallinales o Sporolithales.

Palabras clave: Algas calcáreas, taxonomía, Melobesioideae, Hapalidiales, Rhodophyta.

\section{INTRODUCTION}

Vladimir Petrovich Maslov was a Russian author who worked from 1929 to 1973 on Silurian to Miocene sedimentary rocks from the former USSR (Bassi et al., 2002). His research concentrated on benthic calcareous algae and he published a number of contributions on the palaeontology and biostratigraphic significance of fossils of this group. His main results were presented in two monographs published by the Russian Academy of Sciences of Moscow in 1956 and 1962. In these monographs, he described a large number of coralline algal species and infra-specific taxa (67 in 1956 and 97 in 1962), establishing 41 new taxa (Bassi et al., 2002). As in other palaeontological studies of the 20th century, the diagnostic criteria used by Maslov $(1956 a, 1962)$ to separate genera and infra-generic taxa are different from those used in the present-day morpho-anatomic taxonomy of coralline algae. Therefore, the significance of the taxon names in a modern taxonomic context cannot be fully assessed from the original illustrations and descriptions in Russian by Maslov (1956a, 1962). The large number of taxa established by Maslov warranted the interest of re-studying his original collections in order to identify the types of the taxa, select lectotypes for taxa with no previously established type, and describe and illustrate the types focusing on characters with diagnostic relevance. This paper is the fifth contribution to the taxonomic revision of taxa described by Maslov. Previous contributions focused on the study of the encrusting foraminifer Solenomeris afonensis Maslov, originally described as an alga (Bassi, 2003), the re-assessment of the coralline genera established by Maslov (Bassi et al., 2005), the re-examination of the types of the species attributed by Maslov (1956a, 1962) to Lithophyllum and Melobesia (Braga et al., 2005), and to Archaeolithothamnium (Bassi et al., 2007).

\section{MATERIAL AND METHODS}

The original material of Maslov is preserved as thin sections stored mostly in two boxes at the laboratory of palaeophycology in the Geological Institute at the Russian Academy of Sciences of Moscow. No hand samples from which the thin sections were cut are conserved. The study of thin-sections was performed using light microscopy. The terminology for anatomical descriptions follows Woelkerling (1988) and Braga et al. (1993), cell and conceptacle dimensions follow Chamberlain et al. (1988) and coralline-algal growth-forms are described according to Woelkerling et al. (1993). 
In accordance with ICN Article 61 (particularly 61.4; McNeill et al., 2012), the orthography of names has been standardized, and errors corrected. Non-standardized variants and other incorrect spellings used by authors are given in parentheses (i.e., Mesophyllum schenckii var. corticesum as Mesophyllum schenkii var. corticesum; Lithothamnion as Lithothamnium).

\section{SYSTEMATIC PALAEONTOLOGY}

Order HAPALIDIALES Nelson, Sutherland, Farr et Yoon, 2015

Family Hapalidiaceae Gray, 1864

Subfamily Melobesioideae Bizzozzero, 1885

Genus Mesophyllum Lemoine, 1928

The genus Mesophyllum was established by Lemoine (1928) for coralline algae possessing a coaxial core (hypothallium) and multiporate asexual conceptacles. This has also been the traditional palaeontological concept of the genus (Lemoine, 1939; Conti, 1943; Mastrorilli, 1973; Braga et al., 1993; Aguirre \& Braga, 1998; Basso et al., 1998; Braga, 2003; Iryu et al., 2009, 2012; Aguirre et al., 2011, 2012). Woelkerling \& Harvey (1993), however, suggested that spermatangial initials forming simple spermatangial filaments and development of male conceptacle roof from filaments surrounding the spermatangial initials were the only diagnostic characters separating Mesophyllum from other melobesioid genera with relatively similar vegetative characters, namely Clathromorphum and Synartrophython. As spermatangia are not calcified, their preservation potential as fossils is very low, and they are rarely preserved. Consequently, the traditional concept of Mesophyllum continues to be used. In a similar way, Peña et al. (2011) only used vegetative characters to include a new living melobesioid species in Mesophyllum (Mesophyllum sphaericum). As they were unable to observe spermatangial conceptacles, these authors considered the presence of a strongly coaxial medulla composed of concentric arching tiers a character separating Mesophyllum from Synarthrophyton, in which coaxial areas are usually more localized. According to Peña et al. (2011) the occurrence of more than one epithallial cell in peripheral filaments in Clathromorphum (Adey, 1970; Adey \& Johansen, 1972; Lebednik, 1977; Woelkerling, 1988; Harvey et al., 1994; Basso et al., 2004) separates this genus from Mesophyllum.

Two of the eleven species and infraspecific taxa reassessed here were originally ascribed to Mesophyllum by Maslov (Table 1). Basically, Maslov followed Lemoine (1928) and included in Mesophyllum all non-geniculate coralline red algae that have multiporate tetrasporangial conceptacles and a coaxial ventral core (Maslov, 1956a: 13; 1962: 23). Only one, however, shows features warranting its inclusion in Mesophyllum.

Table 1. Taxonomic disposition of the eleven Maslov's species re-assessed in the present study. Classification system in the left column is that used by Maslov and in common use during the period of Maslov's studies. In that scheme, all corallines were placed in a single family (the Corallinaceae) and all species lacking genicula were referred to a single subfamily (the Melobesiae). Classification system in the right column used in the present study follows Harvey et al. (2003a, b), Braga (2003), and Nelson et al. (2015).

\begin{tabular}{lc}
\multicolumn{1}{c}{ Maslov's disposition } & Disposition proposed in this paper \\
\hline $\begin{array}{l}\text { Family Corallinaceae } \\
\text { Subfamily Melobesiae }\end{array}$ & Order HAPALIDIALES Nelson, Sutherland, Farr et \\
& Yoon, 2015 \\
& Family HAPALIDIACEAE Gray, 1864 \\
& Subfamily Melobesioideae Bizzozzero, 1855 \\
& Mesophyllum Lemoine, 1928 \\
Mesophyllum Schenkii var. corticesum Maslov, 1956 & Mesophyllum schenckii var. corticesum \\
Lithothamnium (?) iorii Maslov, 1956 & uncertain generic placement \\
Palaeothamnium kossovense Maslov, 1962 & uncertain generic placement \\
Mesophyllum kutense Maslov, 1962 & uncertain generic placement \\
Lithothamnium microcellulosum Maslov, 1956 & uncertain generic placement \\
Lithothamnium praefruticulosum Maslov, 1956 & uncertain generic placement \\
Lithothamnium tchernomoricum Maslov, 1956 & uncertain generic placement \\
& \\
& Order and family uncertain \\
Lithothamnium saxorum var. Korolukae Maslov, 1956 & uncertain generic placement \\
Lithothamnium caucasicum Maslov, 1956 & uncertain generic placement \\
Lithothamnium (?) intergeminum Maslov, 1962 & uncertain generic placement \\
Lithothamnium (?) suhumii Maslov, 1956 & uncertain generic placement \\
\hline
\end{tabular}


Mesophyllum schenckii var. corticesum Maslov, 1956a (Figs 1a, 2a-2b)

1956a Mesophyllum schenckii var. corticesum var. nov. Maslov; Maslov, p. 163-164, Pls. 65-67, Text-fig. 84 (as Mesophyllum schenkii var. corticesum)

1962 Mesophyllum schenckii var corticesum Maslov; Maslov, p. 76, P1. 15, Text-fig. 54 (as Mesophyllum schenkii var. corticesum)

Lectotypification. In describing Mesophyllum schenckii var. corticesum, Maslov (1956a: 163-164) cited a single thin section numbered 1048 and designated it as holotype. After examining that thin section, however, we have concluded that Maslov based his account on material belonging to two different taxa, thus necessitating designation of a lectotype (ICN Art 9.2, 9.14).

One taxon, designated here as lectotype of Mesophyllum schenckii var. corticesum and illustrated here in Figs 2a$2 \mathrm{~b}$ and identifiable in Maslov (1956a: pl. 65, fig. 2), is characterized by an encrusting to foliose growth-form, a conspicuously coaxial core, and comparatively small multiporate conceptacles. The other taxon, not illustrated here but visible along with the lectotype in Maslov (1956a: pl. 65, fig. 2), consists of part of a protuberance with numerous comparatively large buried multiporate conceptacles and a basal region with a plumose ventral core. In accord with ICN Art 9.14, the encrusting to foliose, coaxial material has been designated as lectotype because corresponds more nearly with the original description (Maslov 1956a: 163-164). The protuberant thallus has not been identified, but the lack of a coaxial core excludes it from Mesophyllum.

Remaining individuals illustrated in the protologue (Maslov 1956a: pl. 65, fig. 1; pl. 66, figs 1-2; pl. 67, figs 1-2; text-fig. 84) do not occur in thin-section 1048, and we have not found them on other thin-sections examined during this study.

Age and locality. Badenian (Middle Miocene), Opolie, road Lagodov-Sivorosch, western slope of Vysokaja Tura, Lvov province, West Ukraine.

Examination of the lectotype of Mesophyllum schenckii var. corticesum. The designated lectotype includes encrusting-foliose undulating thalli or branches of a single thallus, up to $500 \mu \mathrm{m}$ in thickness. The thalli have a dorsiventral organization and monomerous construction with a single system of filaments that are coaxially arranged in the ventral core $(c a .100-200 \mu \mathrm{m}$ thick) and curve to become perpendicular to the thallus surface. Cells in the coaxial core are about $10-15 \mu \mathrm{m}$ in diameter and $30-35 \mu \mathrm{m}$ long. The peripheral region is $200-$ $250 \mu \mathrm{m}$ thick and shows zonation. Cell length decreases from bottom to top in several growth zones (75-120 $\mu \mathrm{m}$ thick), and are about 8-10 $\mu \mathrm{m}$ in diameter and 12-15 $\mu \mathrm{m}$ high in the dorsal portion. Cell fusions are conspicuous. No epithallial cells are evident.

Two multiporate conceptacles are present (chambers: $225 \mu \mathrm{m}$ in diameter and $175 \mu \mathrm{m}$ high; $300 \mu \mathrm{m}$ in diameter and $160 \mu \mathrm{m}$ high; Figs 2a-2b). One of them is filled with adventitious cells. The pore canals are hardly visible and seem to be surrounded by cells similar to others in the conceptacle roof.

Remarks. The presence of cell fusions and multiporate conceptacles in the holotype means that Mesophyllum schenckii var. corticesum belongs to the Hapalidiaceae, subfamily Melobesioideae. These features combined with the coaxial growth of the core filaments result in placement in Mesophyllum as traditionally circumscribed. The status of Mesophyllum schenckii var. corticesum remains uncertain. The photographs and description of the holotype of Mesophyllum schenckii Howe, 1934 (Howe, 1934: 512-513, pl. 52, note the spelling of the name by Maslov, 1956a, 1962, is different) indicate that this species encompasses plants with protuberances. Examination of the isotype (Woelkerling, 1998) sent by the author to the Muséum d'Histoire Naturelle, Paris (Howe, 1934, p. 511) confirms the occurrence of protuberances in Howe's species. In the original interpretation of Mesophyllum schenckii var. corticesum by Maslov (1956a), the taxon included plants with protuberances as well. As discussed before, the lectotype is restricted to encrusting-foliose plants and it is difficult to assess whether it can be considered conspecific with $M$. schenckii. The size and shape of conceptacles is similar in both taxa. The shape and size of cells surrounding the conceptacle pores are similar to cells in the rest of filaments in conceptacle roof in the examined isotype of $M$. schenckii. This character relevant in the separation of species of Mesophyllum (Harvey et al., 2003a; Kaleb et al., 2011) cannot be conclusively observed in the lectotype of Mesophyllum schenckii var. corticesum.

Mesophyllum schenckii var. corticesum has been identified by Fravega et al. (1984, 1993, no illustration) in the Miocene deposits of the Piedmont Basin (NW Italy).

\subsection{Melobesioid taxa of uncertain generic placement}

Remarks. Nine of the 12 species dealt with in this paper were originally ascribed to Lithothamnion by Maslov (1956a), who used the rejected name Lithothamnium Philippi, 1837 (Woelkerling, 1985; Table 1). Maslov (1956a: 14; 1962: 57) followed Lemoine (1911) and included in Lithothamnion non-geniculate coralline red algae with multiporate (tetrasporangial) conceptacles, monomerous construction, and non-coaxial core. Phymatolithon and Clathromorphum, which show these same features, were 


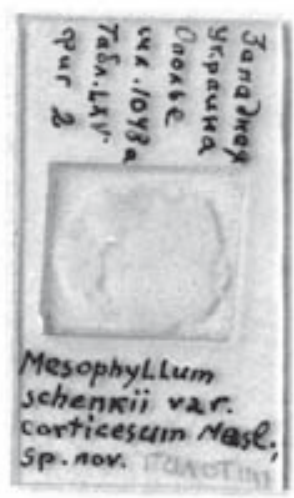

a

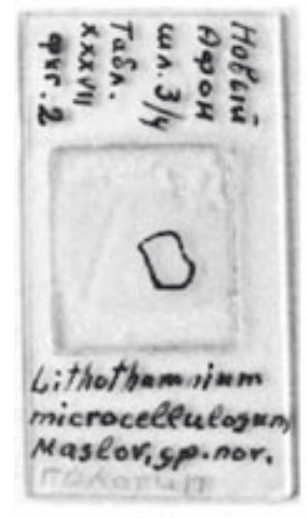

f

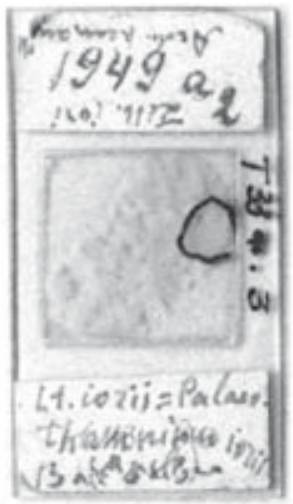

b

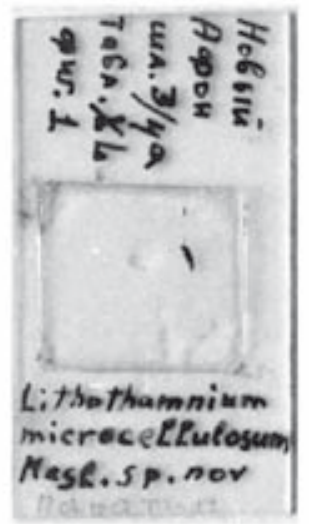

g

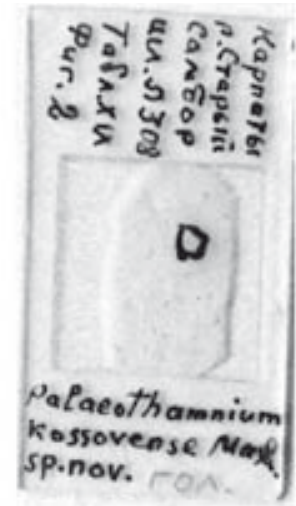

c

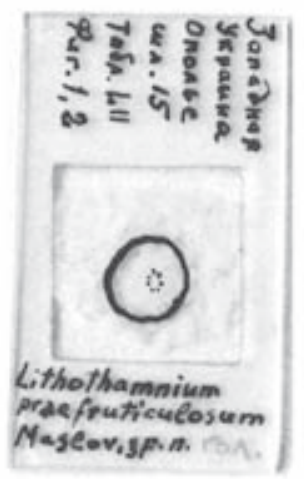

h

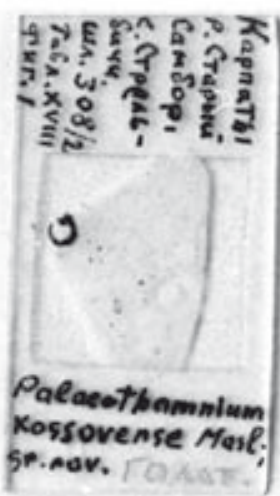

d

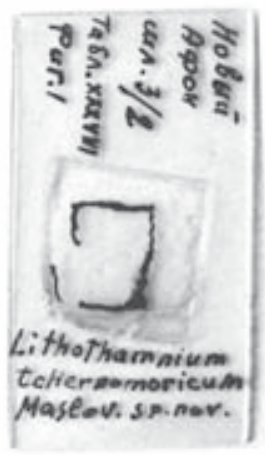

i

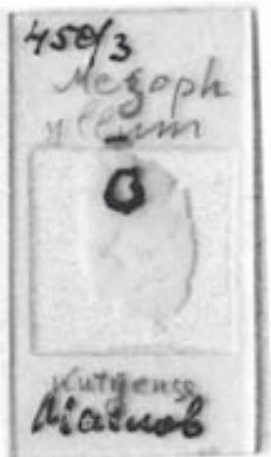

e

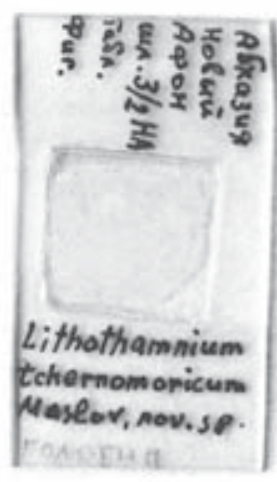

j

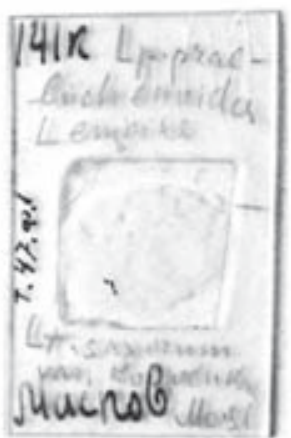

k

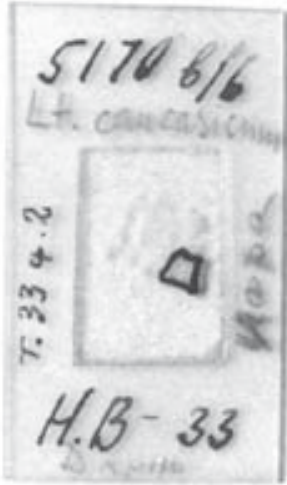

I

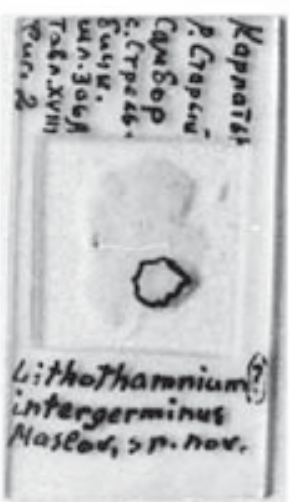

m

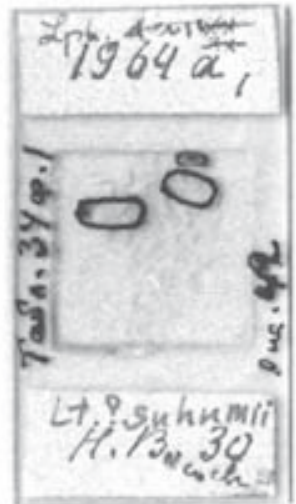

n

Figure 1. Thin sections from Maslov's collection at the Geological Institute, Russian Academy of Sciences, Moscow. a) Mesophyllum schenckii var. corticesum (as Mesophyllum schenkii var. corticesum) Maslov, 1956a; 1048, holotype. b) Lithothamnion (?) iorii Maslov, 1956a; 3504/1949a/2, holotype. c, d) Palaeothamnium kossovense Maslov, 1956a; 308, holotype; 308/2. e) Mesophyllum kutense Maslov, 1962; 450/3, holotype. f, g) Lithothamnion microcellulosum Maslov, 1956a; 3504/3/4, holotype; 3504/3/4a. h) Lithothamnion praefruticulosum Maslov, 1956a; 15, 'Lithothamnium praefruticulosum Maslov sp. n.', holotype. i, j) Lithothamnion tchernomoricum Maslov, 1956a; 3504/3/2, holotype; 3504/3/2HA. k) Lithothamnion saxorum var. korolukae Maslov, 1956a; 3504/141. I) Lithothamnion caucasicum Maslov, 1956; 5170b. m) Lithothamnion (?) intergeminum Maslov, 1962; 306Л, holotype. n) Lithothamnion (?) suhumii Maslov, 1956a; thin section 1964a of the type collection.

rejected as distinct genera by Lemoine (1911). In his first monograph, Maslov (1956a: 14) who did not mention Clathromorphum, indicates that Phymatolithon is characterised by concave conceptacle roofs but the genus is not cited again in his later publications.
Nine genera of Melobesioideae are recognized in modern accounts of living coralline algae (Harvey et al., 2003a, b) and five of them include species with monomerous construction that do not show coaxial growth. According to the modern concept of the genus, Lithothamnion includes 
only those Melobesioideae with monomerous construction throughout, in which the distal walls of epithallial cells are flattened and flared (Woelkerling, 1983, 1985, 1988; Harvey et al., 2003a). This latter character separates Lithothamnion from the other monomerous melobesioid genera: Clathromorphum, Kvaleya, Mesophyllum, Phymatolithon, and Synarthrophyton. A strongly coaxial core can be used to distinguish Mesophyllum from the rest of the members of the subfamily (see above; e.g., Peña et al., 2011) and Kvaleya is a monospecific genus based on a small, "parasitic" species which shows haustoria penetrating the host cells. Phymatolithon might also be separated from other monomerous melobesioids as it presents subepithallial initials as short as or shorter than the immediately subtending cells while initials in the rest of the genera are as long as or longer than the underlying cells. Uncalcified or developmental features, such as spermatangial filaments or male conceptacle development, can also be used to separate genera within the subfamily Melobesioideae but they are very rarely preserved in fossil thalli. If only calcified features are taken into account, Lithothamnion cannot be separated from Phymatolithon, Clathromorphum and Synarthrophyton in the absence of epithallial cells, which also prevents the identification of subepthallial initials. Epithallial cells are frequently preserved in fossil coralline thalli and can be used to recognize Lithothamnion (Braga et al., 1993; Aguirre et al., 1996, 2012; Vannucci et al., 2010) or Phymatolithon (Rasser \& Piller, 1999). In most fossil monomerous melobesioids with non-coaxial core, however, epithallial cells are not preserved or their poor preservation does not allow to confidently assessing whether they are flared. In all these cases, the application of modern botanical taxonomy implies that the specimens cannot be assigned to any defined genus and must be considered as indeterminate Melobesioideae (e.g., Iryu et al., 2009, 2012). The correct application of the current taxonomy for living corallines to fossil thalli, therefore, involves the impossibility of using a large number of species names established in the palaeontological literature based upon species types lacking epithallial cells. Some of these species names, however, were established on types showing other remarkable characters, which might potentially be used to identify and name fossil melobesioids at the specific level, even if the species could not be assigned to any particular genus (e.g., Aguirre \& Braga, 1998; Vannucci et al., 2009, 2010; Aguirre et al., 2011, 2012; Iryu et al., 2012). This is the case of five of the Maslov's species of hapalidiales originally attributed to Lithothamnion (as Lithothamnium) and Palaeothamnium.

Lithothamnion iorii Maslov, 1956a

(Figs 1b, 2c-2e)

1956a Lithothamnium (?) iorii sp. nov. Maslov, 1956a; Maslov, p. 115-116, Pl. 33, Fig. 3, Text-fig. 45

1962 Palaeothamnium iorii Maslov; Maslov, p. 5354, Text-fig. 28

Basionym. Lithothamnion (?) iorii Maslov (as Lithothamnium), 1956a, p. 115-116, Pl. 33, Fig. 3, Textfig. 45.

Holotype. Designated by Maslov (1956a: 116), thin section 3504/1949a/2, labelled ' $L t$ iorii = Palaeothamnium iorii Maslov', illustrated in pl. 33, fig. 3, text-fig. 45 (Fig. 1b).

Age and locality. Danian, Iori river, Caucasus, Georgia.

Examination of the holotype. The thin section containing the holotype includes one thin encrusting undulating thallus, $625 \mu \mathrm{m}$ thick and up to $6.3 \mathrm{~mm}$ long (Fig. 2c). The thallus has a dorsiventral monomerous organization with a plumose ventral core 190-250 $\mu \mathrm{m}$ thick (Figs 2d-2e). The section is oblique to the filaments but it shows that they curve dorsally to become perpendicular to the thallus dorsal surface. The peripheral region ranges from $250 \mu \mathrm{m}$ to $300 \mu \mathrm{m}$ in thickness. Cells are about 8-10 $\mu \mathrm{m}$ in diameter and 20-30 $\mu \mathrm{m}$ long in the core region. In the peripheral region, the cells decrease in length from bottom to top of marked growth zones parallel to the thallus surface (8-10 $\mu \mathrm{m}$ in diameter and $10-15 \mu \mathrm{m}$ high) and are particularly larger at the flanks of developing conceptacles (about $10-15 \mu \mathrm{m}$ in diameter and up to 20

Figure 2. a-b) Mesophyllum schenckii var. corticesum Maslov, 1956a, lectotype, thin section 1048, labelled 'Mesophyllum schenkii var. corticesum Masl. sp. nov.'; (a, b) longitudinal and oblique sections of an encrusting-foliose thallus showing the coaxial arrangement of the ventral filaments (vp) with cell fusions (black arrows) between adjacent cell walls and multiporate conceptacles (white arrows point to pore canals). c-e) Lithothamnion iorii Maslov, 1956a, holotype, thin section 3504/1949a/2, labelled 'Lt iorii = Palaeothamnium iorii Maslov'; (c) thin encrusting undulating thallus bearing three multiporate conceptacles (arrows); (d-e) close-ups of multiporate conceptacles showing the thick plumose ventral core (vp), cell fusions (black arrows) and the elongated cells perpendicular to the surface of the conceptacle roof (white arrows). f-h) Lithothamnion kutense (Maslov), holotype, thin section 450/3, labelled as 'Mesophyllum kutense Maslov'; (f) oblique transversal sections of two branches showing conceptacles (arrows) localized in the outer growth stage of the thallus; (g) close-up of Fig. $2 \mathrm{f}$ showing the renewed growth with a plumose ventral core (vp, black arrow) and multiporate conceptacles (white arrows); h) detail of a multiporate conceptacles showing the pore canals (arrows). 

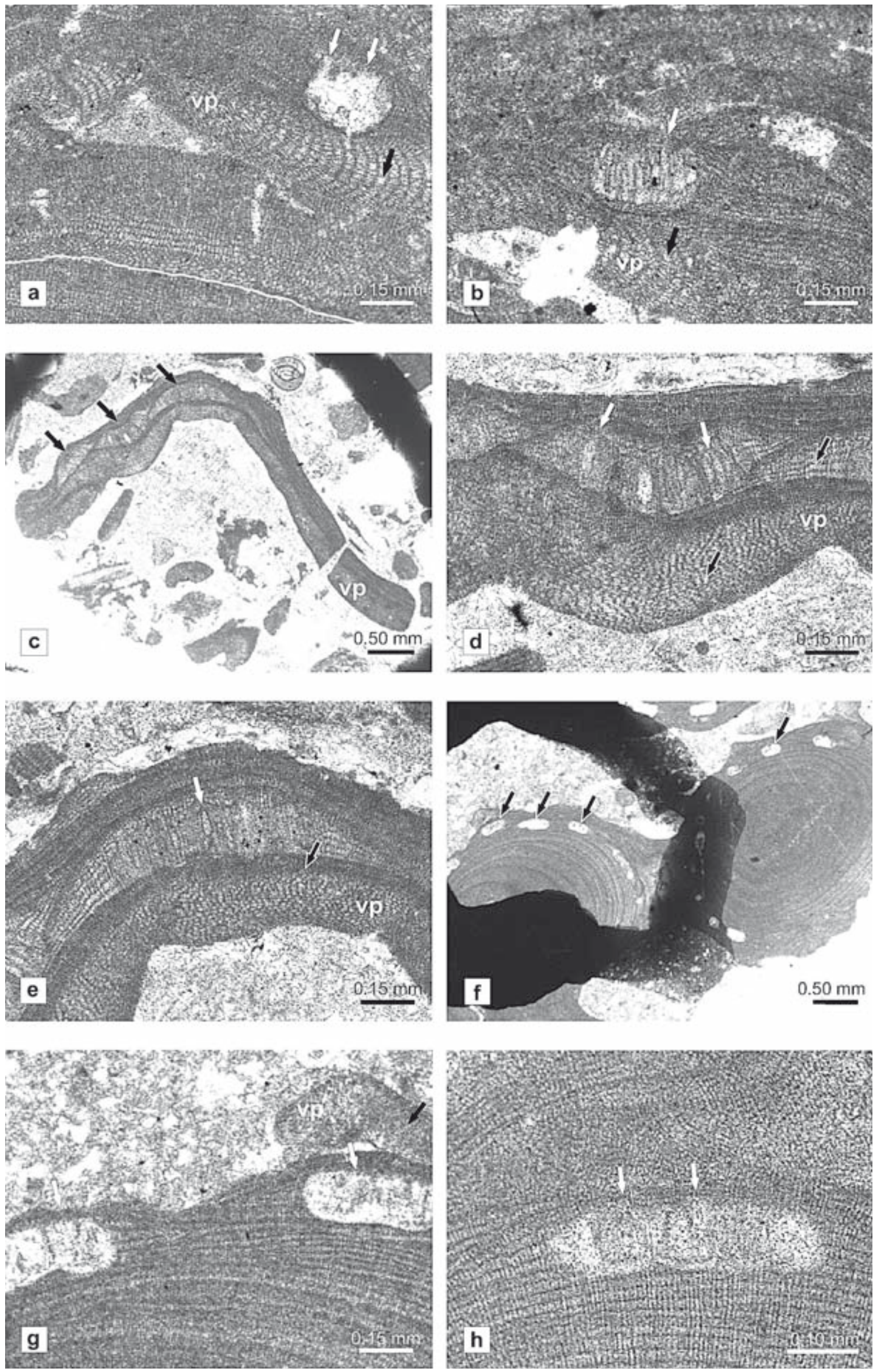
$\mu \mathrm{m}$ high). Cells of adjacent filaments are connected by cell fusions. No epithallial cells and subepithallial initials can be recognized.

Oblique sections of three young or immature conceptacles are present. They protruded above the surrounding thallus surface and are 500-600 $\mu \mathrm{m}$ in diameter and 200-250 $\mu \mathrm{m}$ high (protologue data: 300-500 $\mu \mathrm{m}$ in diameter and $100 \mu \mathrm{m}$ high). Remnants of filaments involved in conceptacle formation, with elongated cells perpendicular to the roof surface, which are characteristic of multiporate conceptacles, can be observed within the conceptacles (Figs 2d-2e) but not fully developed pore canals occur.

Remarks. The occurrence of cell fusions and multiporate conceptacles in the holotype supports placement of this taxon in the Hapalidiaceae, subfamily Melobesioideae (e.g., Harvey et al., 2003a, b). Maslov (1962) attributed this species to the genus Palaeothamnium Conti 1946, characterised by the elongation of cells during tetra/bisporangial conceptacle development according to its author (Basso et al., 1997). Aguirre et al. (1996), however, demonstrated that such elongation occurs in several genera of the subfamily Melobesioideae and considered Palaeothamnium a younger heterotypic synonym of Lithothamnion. The absence of epithallial cells in the type of Lithothamnion iorii Maslov, 1956a prevents any confident generic assignment of the species within the subfamily Melobesioideae.

This species has been reported in the Paleocene and Early Eocene of Corsica, Paris Basin, Aude (France), Sardinia and SE Calcareous Alps (Poignant \& Chaffaut, 1970; Poignant, 1977; Dieni et al., 1979; Segonzac, 1979; Moussavian, 1993) and Early Oligocene from the NW India (Misra et al., 2001). Its status as a distinct species and its relationships to other melobesioids is uncertain.

\section{Palaeothamnion kossovense Maslov, 1962}

(Figs 1c-1d, 3)

1962 Palaeothamnium kossovense Maslov; Maslov, $\mathrm{p}$. 54-56, Pl. 18, Figs 1, 4, Pl. 19, Figs 1-4, Text figs 29-32

1988 Palaeothamnium kossovense Maslov; Studencki, p. 19, Pl. 3, Figs 2, 5

1989 Palaeothamnium kossovense Maslov; Pisera \& Studencki, p. 195, Pl. 6, Fig. 1

Basionym. Palaeothamnium kossovense Maslov, 1962, p. 54-56, Pl. 18, Figs 1, 4, Pl. 19, Figs 1-4, Text-figs 29-32.

Age and locality. Paleocene, Staryj Sambor (village Strel'bichi), Karpathians, Ukraine.

Holotype. Maslov (1962: 54) designated as holotype the thin section 308, labelled 'Palaeothamnium kossovense
Masl. sp. nov., 308' (Fig. 1c). In the protologue, immediately below the name, the author refers to tab. 19, figs 1-4 and text-figs 29-32 as illustrations of the species. However, only the picture in tab. 19 , fig. 2 corresponds to the thallus in section 308. The rest of thalli illustrated in tab. 19, figs 1, 3 and 4, as well as in tab. 18, figs 1-2 and 4 (not mentioned in the text) do not appear either in section 308 or in section 308/2, conserved in the collection and also labelled 'Palaeothamnium kossovense Masl. sp. nov.' (Fig. 1d). They probably were in the lost thin sections mentioned in the protologue $(223 / 26,249$, and $306 / 2$, that might be an erratum for $308 / 2$ ).

Examination of the holotype. The holotype (thin section 308) is an abraded thallus fragment $4.5 \mathrm{~mm}$ long and $2.75 \mathrm{~mm}$ wide, probably part of a protuberance of a larger thallus (Fig. 3a). The thallus has a dorsiventral monomerous organization with a thick ventral plumose core (up to $0.37 \mathrm{~mm}$ thick) in which the filaments run parallel to the ventral surface for a very short distance and curve upwards while dividing to become perpendicular to the dorsal surface (Fig. 3c). Core region cells are mostly 8-12 $\mu \mathrm{m}$ in diameter and 20-25 $\mu \mathrm{m}$ long (protologue data: 5-7 $\mu \mathrm{m}$ in diameter and 10-25 $\mu \mathrm{m}$ long). Cells in the peripheral region slightly decrease in size from bottom to top of faintly defined growth zones and are 5-8 $\mu \mathrm{m}$ in diameter and 10-20 $\mu \mathrm{m}$ high (protologue data: 5-7 $\mu \mathrm{m}$ in diameter and 10-20 $\mu \mathrm{m}$ high). Cell fusions are present. There is a clear lateral alignment of cells of adjacent filaments. No epithallial cells or subepithallial initials are preserved.

Three structures consisting of elongated cells overlying a layer of cells larger than the ones in the rest of the peripheral region can be interpreted as remains of immature conceptacles that have become buried in the thallus (Figs 3d-3f). Elongation of cells in the conceptacle primordium is a common feature of development of tetra/bisporangial conceptacles in melobesioids (see Aguirre et al., 1996 for references). Elongated and larger "cells", wider than surrounding filaments probably correspond to developing tetra/bisporocytes. The structures are $160-180 \mu \mathrm{m}$ wide and $70-100 \mu \mathrm{m}$ in height. No pore canals can be observed at the top of the structures.

Remarks. The occurrence of cell fusions and developing multiporate conceptacles in the holotype indicate that it belongs to the Hapalidiaceae, subfamily Melobesioideae. The inclusion of this species in Palaeothamnium Conti 1946 by Maslov (1962) was based on the occurrence of structures with elongated cells in the specimens that he examined and described. This feature, however, reflects the initial steps of conceptacle development in melobesioids and cannot be considered diagnostic at the genus level (Aguirre et al., 1996). Although the type species of Paleothamnium (P. archaeotypum) belongs to 

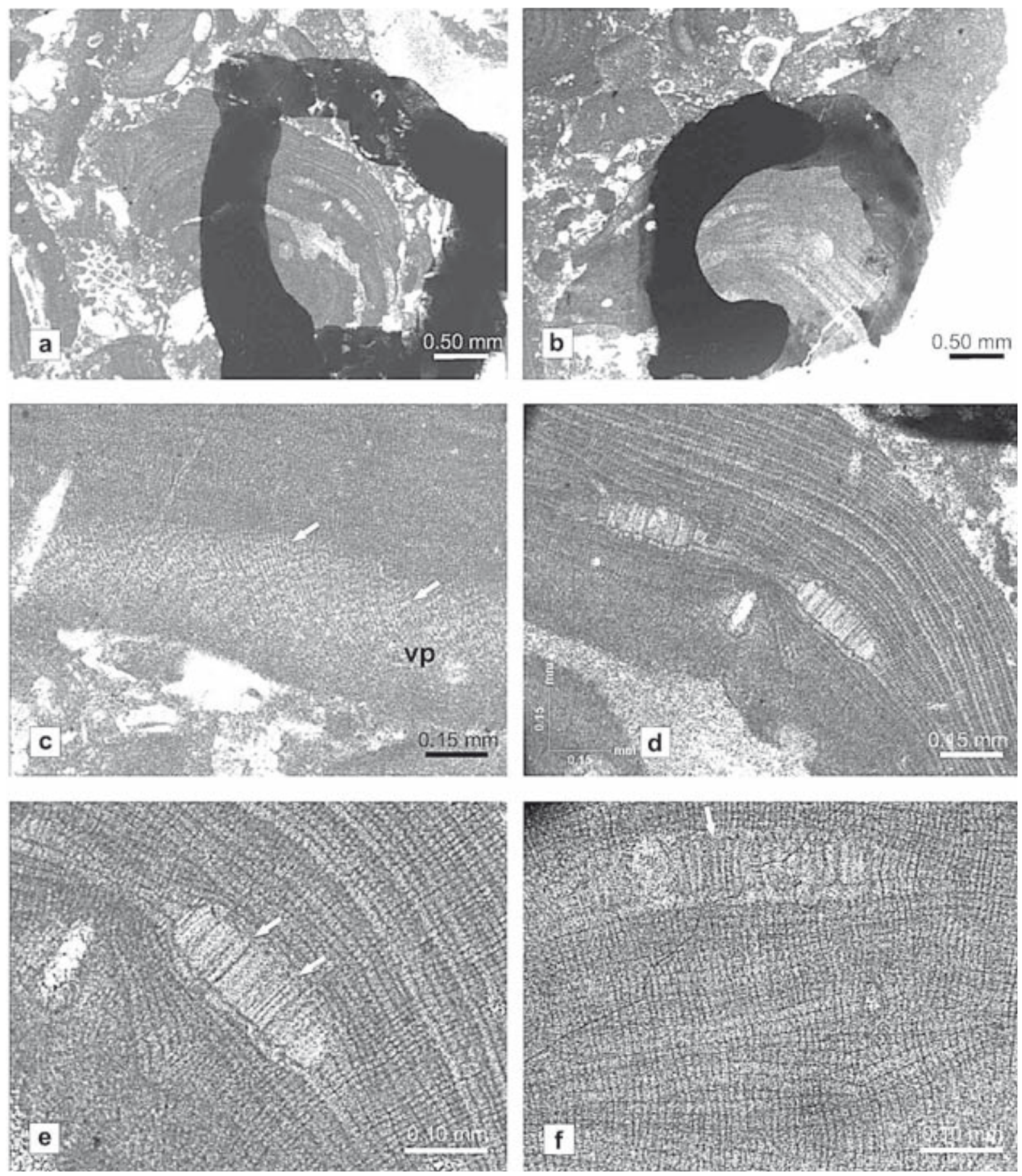

Figure 3. Palaeothamnium kossovense (Maslov); a, c-e) holotype (thin section 308); b, f) (thin section 308/2). a-b) Nearly longitudinal sections of protuberances. c) Part of the thick ventral plumose core (vp) in which cell fusions are present (arrows). d-f) Close-ups of the structures (d-e are from $\mathbf{a} ; \mathbf{f}$ is from $\mathbf{b}$ ), characterized by elongated cells (arrows) possibly representing immature conceptacles that have become buried in the thallus.

Lithothamnion (Aguirre et al., 1996), Palaeothamnium kossovense Maslov, 1962 cannot be confidently assigned to any genus within the subfamily Melobesioideae due to the lack of epithallial cells in its type.

This species has been reported in the Paleocene and Early Eocene from the Carpathian Mountains, Sardinia and
SE Calcareous Alps (Poignant \& Caffautt, 1970; Dieni et al., 1979; Moussavian, 1993) and Middle Miocene from Poland (Studencki, 1988; Pisera \& Studencki, 1989).

Mesophyllum kutense Maslov, 1962

(Figs 1e, 2f-2h) 
1962 Mesophyllum kutense sp. nov. Maslov; Maslov, p. 75-76, Pl. 17, Fig. 2, Text-fig. 53

Holotype. Designated by Maslov (1962: 76), thin section 450/3, labelled as 'Mesophyllum kutense Maslov' (Fig. 1e). Text-fig. 53 is a drawing of an oblique tangential section of the multiporate conceptacle illustrated in $\mathrm{pl}$. 17, fig. 2 .

Age and locality. Paleogene, Stari Kuty, West Ukraine.

Examination of the holotype. The holotype shows an oblique transversal section of two branches joined by a bridge of an encrusting part of the thallus (Fig. 2f). The sections of the large branches are $2.5 \mathrm{~mm} \times 2.0 \mathrm{~mm}$ and $2.5 \mathrm{~mm} \times 3.0 \mathrm{~mm}$, respectively. The thallus is monomerous with a plumose ventral core observable in renewed growth, about $80 \mu \mathrm{m}$ thick, over previous thallus surfaces marked by conceptacle roofs (Fig. 2g). Cells in the core are about $6 \mu \mathrm{m}$ in diameter and $12 \mu \mathrm{m}$ long (no protologue data). Length of cells in the peripheral region decrease in size from bottom to top of faint growth zones $(5-8 \mu \mathrm{m}$ in diameter and 10-15 $\mu \mathrm{m}$ high; protologue data: $6 \mu \mathrm{m}$ in diameter by $8-16 \mu \mathrm{m}$ high). Cells of adjacent filaments are connected by cell fusions. No epithallial or subepithallial cells can be recognised.

There are eight multiporate conceptacles present. In their longitudinal-tangential sections they are relatively flat with round sides and slightly protruded on the thallus surface (chambers 300-350 $\mu \mathrm{m}$ in diameter and 100-170 $\mu \mathrm{m}$ high; protologue data: $140-360 \mu \mathrm{m}$ in diameter by 80 $140 \mu \mathrm{m}$ high). The pore canals are cylindrical (10-15 $\mu \mathrm{m}$ in diameter and 30-40 $\mu \mathrm{m}$ high; Fig. $2 \mathrm{~h}$ ).

Remarks. The presence of cell fusions and multiporate conceptacles in the holotype places Mesophyllum kutense within the family Hapalidiaceae, subfamily Melobesioideae (e.g., Braga, 2003; Table 1). The absence of coaxial growth precludes placement of the type in Mesophyllum as traditionally delimited by palaeontologists (see above) and the absence of epithallial cells prevents its placement in any of the other monomerous non-coaxial melobesioid genera. Consequently, Mesophyllum kutense Maslov,
1962 is treated here as other monomerous non-coaxial fossil melobesioids lacking preserved epithallial cells. Its status as a distinct species and its relationships to other melobesioids are uncertain.

This species name has had a low impact in the palaeophycological literature since it has been referred only three times in Early Miocene deposits from Italy (Fravega et al., 1993, no illustration).

\section{Lithothamnion microcellulosum Maslov, 1956a} (Figs 1f-1g, 4a-4c)

1956a Lithothamnium microcellulosum sp. nov. Maslov; Maslov, p. 136, Pl. 37, Fig. 2, Pl. 40, Fig. 1.

1962 Lithothamnium microcellulosum Maslov; Maslov, p. 65-66, Text-fig. 40.

Holotype. Designated by Maslov (1956a: 136), thin section 3504/3/4 (Fig. 1f). This section contains the specimen illustrated in pl. 37, fig. 2. There is another thin section from the same sample, labelled 3504/3/4a (Fig. 1g), which according to the handwriting on its surface should include the detail illustrated in pl. 40, fig.1. However, we were not able to identify the part of the thallus shown in that picture. The same conceptacle in the holotype shown in pl. 37 , fig. 2 was also illustrated as a drawing in textfig. 40 in Maslov (1962).

Age and locality. Early Eocene, limestones with "Nummulites"; Novyj Afon, Abkhazia, Georgia.

Examination of the holotype. The holotype only contains an abraded fragment $6.5 \mathrm{~mm}$ long and $4 \mathrm{~mm}$ wide, of a protuberance. The section shows superimposed thalli or successive growth stages of a single thallus with dorsiventral monomerous organization with a non-coaxial ventral core of filaments (Fig. 4b). The filaments in the core run parallel to the ventral surface only for a very short distance and immediately bend upwards. Cells in the ventral core are 5-8 $\mu \mathrm{m}$ in diameter and $10-15 \mu \mathrm{m}$ long and cells in the peripheral region are $5-10 \mu \mathrm{m}$ in diameter and 10-15 $\mu \mathrm{m}$ high (protologue data: 4-7 $\mu \mathrm{m}$ in diameter and 7-10 $\mu \mathrm{m}$ high). Cells of adjacent filaments are connected

Figure 4. a-c) Lithothamnion microcellulosum Maslov, 1956a, holotype, thin section 3504/3/4. (a) Longitudinal oblique section of a protuberance showing superimposed thalli bearing multiporate conceptacles; (b) close-up of Fig. 4a showing the non-coaxial ventral core of filaments (vp) with cell fusions (arrow); (c) multiporate conceptacle protruding above surrounding thallus surface with an undulated floor higher at its centre (black arrow) and round sides. d-e) Lithothamnion praefruticulosum Maslov, 1956a, thin section 3504/15, labelled as 15, 'Lithothamnium praefruticulosum Maslov sp. n.'; (d) longitudinal section of the lumpy protuberance showing several growth stages with multiporate conceptacles; (e) close-up of Fig. 4d illustrating a longitudinal oblique section of a multiporate flat conceptacle with rounded sides (arrows point to pore canals). f-g) Lithothamnion tchernomoricum Maslov, 1956a, holotype, thin section 3504/3/2; (f) the abraded fragment of a thallus protuberance, encrusted by an acervulinid foraminifer (ac), with buried conceptacles (arrows); (g) the transversal section of the ventral part (vp) of the thallus does not show the thallus organization (arrows point to cell fusions). 

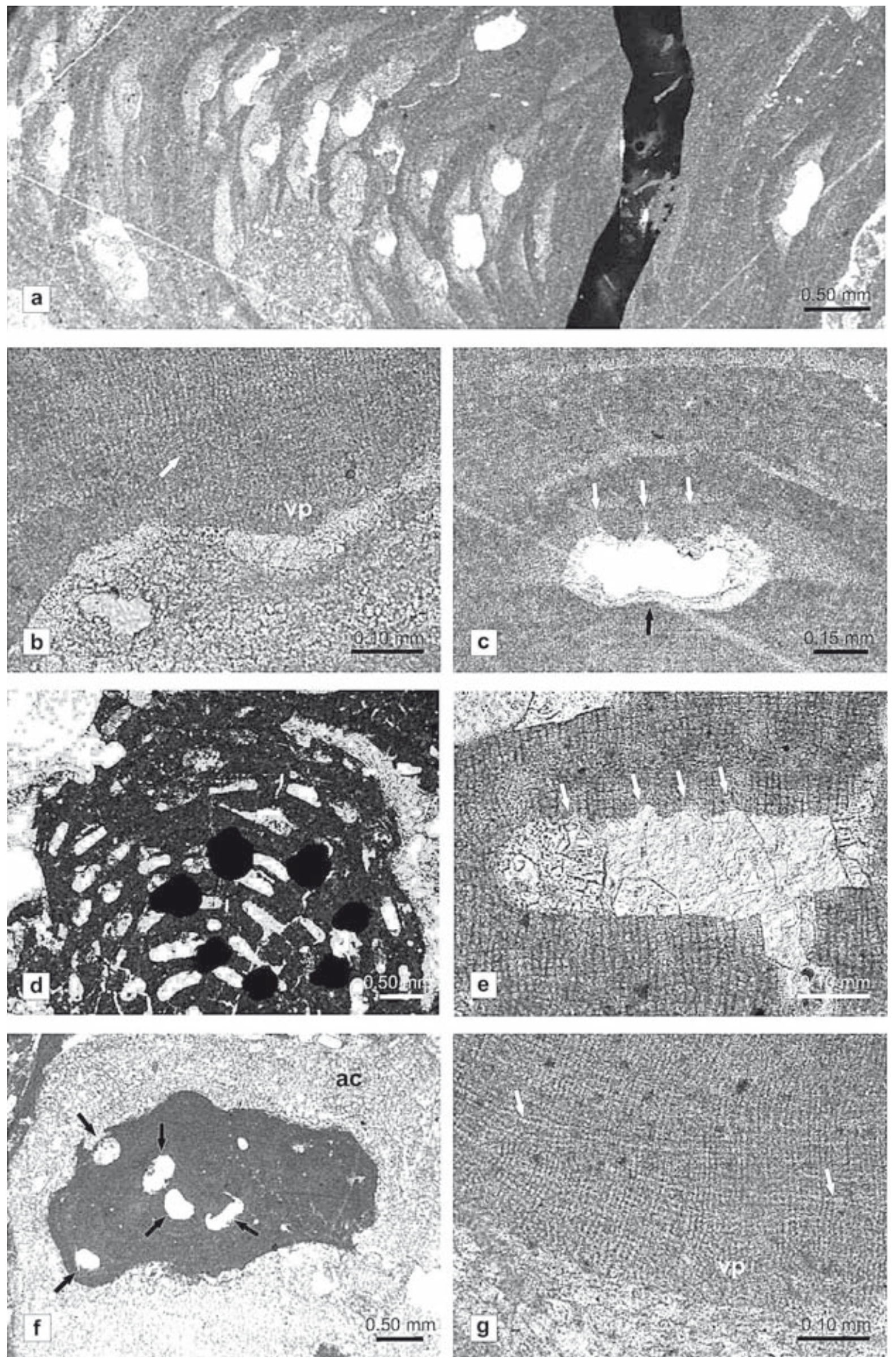
by cell fusions. No distinct growth zones occur but growth stages are marked by renewed growth over the surface of buried conceptacles. No distinct epithallial or subepithallial cells can be recognized.

There are eight multiporate conceptacles present (chambers 500-600 $\mu \mathrm{m}$ in diameter and 225-250 $\mu \mathrm{m}$ high; protologue data: $500 \mu \mathrm{m}$ in diameter and 100-150 $\mu \mathrm{m}$ high; Figs $4 \mathrm{a}, 4 \mathrm{c})$. The conceptacles protrude above surrounding thallus surface. The larger sections of conceptacles show an undulated floor higher at its centre and round sides. In these sections, the base of conceptacle roof is undulated as well. The floor seems to "carve" the underlying peripheral filaments. Cells at the conceptacle flanks and roof are larger and less calcified than surrounding cells in the peripheral region. Conceptacle roofs are 10-15 (16) cell thick. Pore canals are $c .35 \mu \mathrm{m}$ in diameter and 70-75 $\mu \mathrm{m}$ high. Cells lining the pore canals are poorly preserved.

Remarks. The type of Lithothamnion microcellulosum Maslov, 1956a, with multiporate conceptacles and cell fusions, belongs to the Hapalidiaceae, subfamily Melobesioideae but cannot be confidently attributed to any genus within this subfamily due to the lack of epithallial cells in its type. Its status as a distinct species and its relationships to other melobesioids is uncertain.

This species has been reported in the Eocene of the Republic of Macedonia (Lemoine, 1977), Oligocene-Early Miocene of Italy (Mastrorilli, 1973), and Middle Miocene of Poland (Studencki, 1988).

\section{Lithothamnion praefruticulosum Maslov, 1956a} (Figs 1h, 4d-4e)

1956a Lithothamnium praefruticulosum sp. nov. Maslov; Maslov, p. 149-150, Pl. 52, Figs 1-2.

1962 Lithothamnium praefruticulosum Maslov; Maslov, p. 68, Pl. 16, Figs $1,3$.

1968 Lithothamnium praefruticulosum Maslov; Mastrorilli, p. 266-267, Pl. 8, Fig. 3.

1983 Lithothamnium praefruticulosum Maslov; Bosence, p. 153-156, Text-fig. 4, Pl. 16, Figs 1-2.

1985 Lithothamnium praefruticulosum Maslov; Pisera, p. 101, Pl. 20, Figs 1-3.

1989 Lithothamnium praefruticulosum Maslov; Pisera \& Studencki, p. 196-197, Pl. 7, Fig. 4, Pl. 8, Fig. 5.

Holotype. Designated by Maslov (1956a: 150), thin section 3504/15, now labelled as 15 , 'Lithothamnium praefruticulosum Maslov sp. n.', with reference to the type locality and figures in the protologue (Fig. 1h). A portion of the thin section is marked by an ink circle.

Age and locality. Badenian (Middle Miocene), Opolie, Lvov province, West Ukraine.
Examination of the holotype. The holotype consists of a longitudinal oblique section of an abraded fragment of a lumpy protuberance $4.5 \mathrm{~mm}$ long and $4 \mathrm{~mm}$ wide, with several growth stages marked by buried conceptacles (Fig. 4d). The ventral side of the thallus cannot be observed but in renewed growth of the thallus over conceptacle roofs the organisation is monomerous with a very thin plumose ventral core of filaments that curve upwards after running parallel to the ventral surface for a very short distance. In the peripheral part of the thallus, cells are $20-22 \mu \mathrm{m}$ in diameter and 20-22 $\mu \mathrm{m}$ long (protologue data: $15 \mu \mathrm{m}$ in diameter and 15-20 $\mu \mathrm{m}$ long). Cells of adjacent filaments are connected by cell fusions. No epithallial cells or subepithallial initials can be recognized.

Longitudinal-tangential sections of more than 20 multiporate conceptacles are present. They are relatively flat (chambers $400-500 \mu \mathrm{m}$ in diameter and $130-150 \mu \mathrm{m}$ high; protologue data: $250-350 \mu \mathrm{m}$ in diameter by 180 $200 \mu \mathrm{m}$ high) with rounded sides and slightly protruded on the thallus surface. The roof is 4-6 cell thick and the pore canals are cylindrical $(20-25 \mu \mathrm{m}$ in diameter and 50 $70 \mu \mathrm{m}$ high; Fig. 4e).

Remarks. The presence of cell fusions and multiporate conceptacles indicate that the holotype of Lithothamnion praefruticulosum Maslov, 1956a belongs to the Hapalidiaceae, subfamily Melobesioideae but the species cannot be assigned to a genus within the family due to the absence of preserved epithallial cells in the holotype. Its status as a distinct species is uncertain.

This species has been reported in the Oligocene-Late Miocene of the Piedmont Basin (Mastrorilli, 1968, 1973; Fravega \& Vannucci, 1982; Fravega et al., 1984, 1993), Early Miocene of Corsica (Bellini \& Mastrorilli, 1975), Middle Miocene of Poland (Studencki, 1988; Pisera \& Studencki, 1989), Middle Miocene of the Transilvanian Basin in Romania (Bucur \& Filipescu, 1994), Late Miocene of Malta (Bosence, 1983).

\section{Lithothamnion tchernomoricum Maslov, 1956a}

(Figs 1i-1j, 4f-4g, 5a)

1956a Lithothamnium tchernomoricum sp. nov. Maslov; Maslov, p. 136-137, Pl. 38, Figs 1-5, Pl. 39, Figs 1-2

1962 Lithothamnium tchernomoricum Maslov; Maslov, p. 71, P1. 17, Text-fig. 49

Holotype. Designated by Maslov (1956a: 137), thin section 3504/3/2 (Fig. 1i). This is the thin section containing the thallus illustrated in the protologue in pl. 38, fig. 1 and pl. 39, figs 1-2. The thallus fragments illustrated in pl. 38, fig. 2, together with Solenomeris have not been identified neither in this section nor in the additional one from the same hand sample (3504/3/2/HA) also preserved in the collection. We have not been able to identify the 

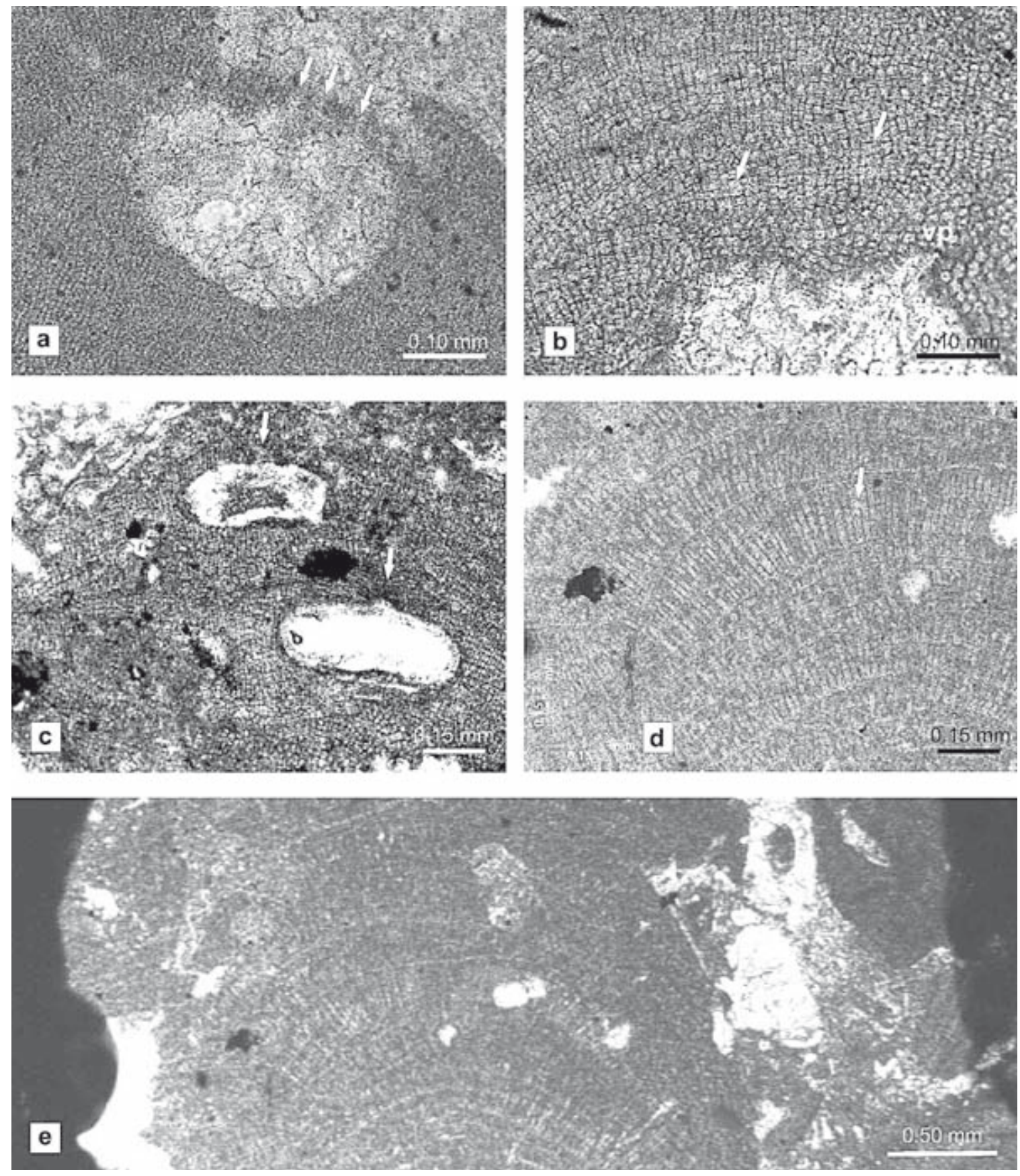

Figure 5. a) Lithothamnion tchernomoricum Maslov, 1956a, holotype; oblique section of a multiporate conceptacle showing cylindrical pore canals (arrows). b-c) Lithothamnium saxorum var. korolukae Maslov, 1956a, thin section 3504/141, 'Lt saxorum var. Korolukae Masl, Lp praelichenoides Lemoine, pl. 47’; (b) plumose core of filaments (vp) showing cell fusions between cells of adjacent filaments (arrows); (c) oblique longitudinal sections of two possible uniporate (arrows) conceptacles. d-e) Lithothamnion intergeminum Maslov, 1962, holotype, thin section 306Л, labelled as 'Lithothamnium (?) intergeminus Maslov sp. nov.'; (d) detail of Fig. 5e showing the fan-like arrangement of the filaments in the protuberance (arrow, cell fusions); (e) oblique section of the protuberance.

cell groups illustrated in drawings in pl. 38, figs 3-5. These three drawings were again published by Maslov in 1962 (text-fig. 49).

Age and locality. Early Eocene, limestones with "Nummulites"; Novyj Afon, Abkhazia, Georgia.
Examination of the holotype. The holotype consists of a longitudinal oblique section of an abraded fragment of a thallus protuberance, $3.5 \mathrm{~mm}$ long and $2.0 \mathrm{~mm}$ wide, with several growth stages marked by buried conceptacles. This fragment constitutes the nucleus of a small macroid made up of an encrusting acervulinid foraminifer (Fig. 4f). 
The section does not allow to assess the nature of the thallus organization and the type of ventral core. Cells in the protuberance are about $10 \mu \mathrm{m}$ in diameter and $20 \mu \mathrm{m}$ long (protologue data: $7 \mu \mathrm{m}$ in diameter by $7 \mu \mathrm{m}$ long) with faint growth zones. Cells of adjacent filaments are connected by cell fusions (Fig. 4g). No epithallial cells or subepithallial initials are preserved.

Oblique sections of five multiporate conceptacles buried in the thallus are present $(350-500 \mu \mathrm{m}$ in diameter and $220-250 \mu \mathrm{m}$ high; protologue data: $220-250 \mu \mathrm{m}$ in diameter by $100 \mu \mathrm{m}$ high). One shows cylindrical pore canals about $25 \mu \mathrm{m}$ in diameter and $40 \mu \mathrm{m}$ high (Fig. 5a).

Remarks. The presence of cell fusions and multiporate conceptacles in the holotype means that Lithothamnion tchernomoricum Maslov, 1956a belongs to the Hapalidiaceae, subfamily Melobesioideae (Table 1). The thallus depicted in Figure 4g is sectioned transversally the direction of core filament growth and, as consequence, the ventral core is not evident because one is seeing a cross section of it rather than a section parallel to the core filaments. As neither the type of thallus organization nor the shape of epithallial cells can be observed in the type, no further precision in the taxonomic assignment can be made and we keep the basionym to refer to this species. This species has never been reported by authors other than Maslov (1956a, 1962, 1973).

\subsection{Taxa of uncertain order and family placement}

The types of the following four taxa, listed here by their basionym, do not show sufficient features to allow order and family placement within the Hapalidiales, Corallinales or Sporolithales (Table 1).

\section{Lithothamnion saxorum var. korolukae Maslov, 1956a} (Figs 1k, 5b-5c)

1956a Lithothamnium saxorum var. Korolukae var. nov. Maslov; Maslov, p. 144, Pl. 47, Text-fig. 65.

1962 Lithothamnium saxorum var. korolukae Maslov; Maslov, p. 69, Text-fig. 46.

Holotype. Designated by Maslov (1956a: 144), thin section 3504/141, 'Lt saxorum var. Korolukae Masl, Lp praelichenoides Lemoine, pl. 47', (Fig. 1k). Text-fig. 65 is a drawing of a monomerous thallus organization that cannot be identified in the thallial fragment in this thin section.

Age and locality. Badenian (Middle Miocene), Toltry, West Ukraine.
Examination of the holotype. The holotype is an abraded fragment of an encrusting thallus, $1.65 \mathrm{~mm}$ long and up to $0.9 \mathrm{~mm}$ thick, intergrown with encrusting foraminifera. The thallus shows a dorsiventral monomerous organization with a plumose core of filaments that run parallel to the ventral surface for a short distance and curve upwards to become perpendicular to the thallus surface in the dorsal peripheral region (Fig. 5b). Core cells are 10-15 $\mu \mathrm{m}$ in diameter and 20-25 $\mu \mathrm{m}$ long (protologue data: 15 $\mu \mathrm{m}$ in diameter by $25-30 \mu \mathrm{m}$ long); peripheral region cells are: $10-15 \mu \mathrm{m}$ in diameter and $12-15 \mu \mathrm{m}$ long (protologue data: $10-15 \mu \mathrm{m}$ in diameter and 10-20 $\mu \mathrm{m}$ long). Cells of adjacent filaments are connected by cell fusions. No epithallial cells are preserved.

Oblique longitudinal sections of two possibly uniporate conceptacles are present (chambers 375$450 \mu \mathrm{m}$ in diameter; 150-170 $\mu \mathrm{m}$ high; Fig. 5c). The sections, however, do not show conclusively whether the conceptacles are multiporate, as interpreted by Maslov (1962: 69) or uniporate.

Remarks. As the nature of the conceptacles in the holotype cannot be assessed $L$. saxorum var. korolukae cannot be attributed to any precise family and subfamily within Hapalidiales or Corallinales with non-geniculate thalli and cell fusions. This taxon has never been reported by other authors.

\section{Lithothamnion caucasicum Maslov, 1956a}

(Figs 11, 6)

1956a Lithothamnium caucasicum sp. nov. Maslov; Maslov, p. 116-117, Pl. 33, Fig. 2, Text-fig. 46.

1962 Lithothamnium caucasicum Maslov; Maslov, p. 60-61, Text-fig. 36.

Holotype. Designated by Maslov (1956a: 117), thin section 5170b, labelled 'Lt caucasicum, pl. 33, fig. 2' (Fig. 11). Text-fig. 46 is a drawing of filaments that cannot be identified in the thallial fragment in this thin section.

Age and locality. Danian, Iori River, Caucasus, Georgia.

Examination of the holotype. The thin section includes two small abraded fragments, $3.5 \mathrm{~mm}$ long and $1.75 \mathrm{~mm}$ wide, and $3 \mathrm{~mm}$ long and $2.5 \mathrm{~mm}$ wide respectively, that probably correspond to transversal (left specimen in Fig. 6) and longitudinal (right specimen) sections of branches of non-geniculate thalli. The fragments consist of a single system of radiating and dividing filaments. Primary cell walls are not laterally aligned, ranging from 8 to $10 \mu \mathrm{m}$ in diameter and from 20 to $25 \mu \mathrm{m}$ in length. Cells in the centre of each branch are longer than the ones in the periphery. Walls separating adjoining filaments are 


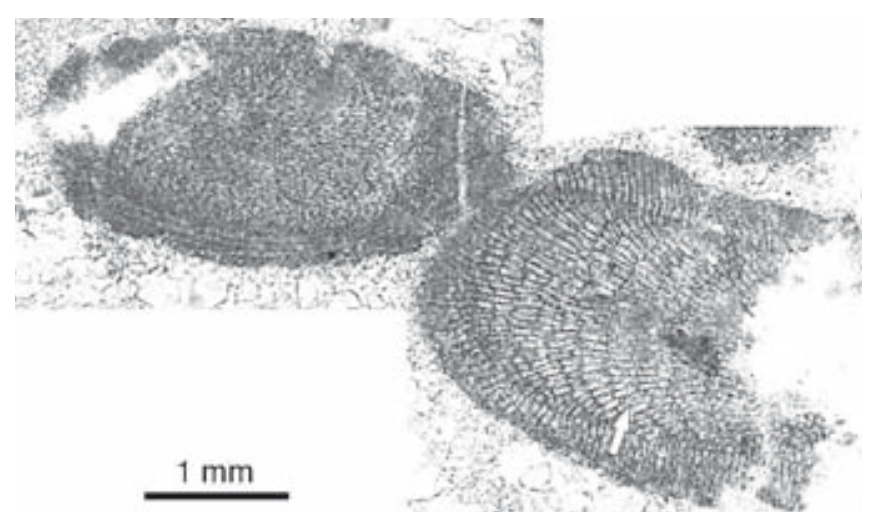

Figure 6. Lithothamnion caucasicum Maslov, 1956a, thin section 5170 b, labelled 'Lt caucasicum, pl. 33, fig. 2'. Two small abraded fragments, constituting the holotype, with no reproductive structures preserved.

relatively well-defined but scarce cell fusions can be recognised. No reproductive structure is present.

Remarks. The occurrence of cell fusions indicates that the type of Lithothamnion caucasicum does not belong to the subfamily Lithophylloideae in the family Corallinaceae. However, the lack of other significant features, such as reproductive structures, prevents any confident assignment of $L$. cancasicum to known taxa within the Hapalidiales, Corallinales or Sporolithales (Table 1).

The name $L$. caucasicum has been used for algae from the Late Cretaceous of the Pyrenees (Poignant, 1981) and Paleocene deposits from Borneo (Johnson, 1966).

Lithothamnion (?) intergeminum Maslov, 1962 (Figs 1m, 5d-5e)

1962 Lithothamnium (?) intergeminum sp. nov. Maslov; Maslov, p. 62-63, Pl. 18, Fig. 2, Text-fig. 37.

Holotype. Designated by Maslov (1962: 62-63), thin section 306Л, labelled as 'Lithothamnium (?) intergeminus Maslov sp. nov.' (Fig. 1m). Text-fig. 37 is a drawing of five filaments that cannot be identified in the thallial fragment in this thin section. The holotype was illustrated in the protologue (Maslov, 1962, pl. 18, fig. 2). A portion of the thin section is marked by an ink circle.

Age and locality. Early Paleogene?, Staryi Sambor, Lvov province, West Ukraine.

Examination of the holotype collection. The thin section contains an oblique section of a protuberance (at least $2.5 \mathrm{~mm}$ in diameter) showing filaments with a fanlike arrangement (Fig. 5e). Cells are slightly longer in the center of the protuberance than in its margins $(15 \mu \mathrm{m}$ in diameter and $37 \mu \mathrm{m}$ in height; protologue data: 10-25 $\mu \mathrm{m}$ in diameter and 35-50 $\mu \mathrm{m}$ high). Cell fusions are common (Fig. 5d). No reproductive structures are present and no epithallial cells can be identified.

Remarks. In the protologue Maslov (1962) did not describe conceptacles. He considered "Lithothamnium (?) intergeminum" as a possible transitional form from "Solenopores" to the genus Lithothamnion (Maslov, 1956a: 63). The absence of reproductive structures precludes any certain placement at order or family levels within the Hapalidiales, Corallinales or Sporolithales (Table 1). This species has been only referred by Maslov (1962).

\section{Lithothamnion (?) suhumii Maslov, 1956a} (Figs 1n, 7)

1956a Lithothamnium (?) suhumii sp. nov. Maslov; Maslov, p. 114, Text-fig. 42.

1962 Lithothamnium (?) suhumii Maslov; Maslov, p. 70, Text-fig. 47.

Basionym. Lithothamnion (?) suhumii Maslov (as Lithothamnium), 1956a, p. 114, Text-fig. 42.

Holotype. Designated by Maslov (1956a: 114), thin section 1964a 'Lt ? suhumii, 30, pl. 34, fig. 1' (Fig. 1n). Text-fig. 42 shows two drawings of monomerous thallial organizations that cannot be identified in the thallial fragment in this thin section.

Age and locality. Danian, Iori River, Caucasus, Georgia.

Examination of the holotype. The holotype consists of a longitudinal to oblique section of a encrusting thallus fragment, $c a .1 .5 \mathrm{~mm}$ long and $0.6 \mathrm{~mm}$ thick. The thallus has a monomerous construction with a thick ventral core that is probably coaxial about $150 \mu \mathrm{m}$ in width and a peripheral region $450 \mu \mathrm{m}$ in width where core filaments or their derivatives curve outwards towards the dorsal surface (Fig. 7). Cells in the ventral region are mostly 20 $\mu \mathrm{m}$ long and $10 \mu \mathrm{m}$ in diameter. Cell in the peripheral region are decrease from 15 to $20 \mu \mathrm{m}$ in length within the conspicuous growth zones and are $8 \mu \mathrm{m}$ in diameter. Cells of adjacent filaments are connected by cell fusions. No reproductive structures or epithallial cells are preserved.

Remarks. The absence of reproductive structures prevents the placement of the holotype in any order and family within the Hapalidiales, Corallinales or Sporolithales. This species has been only reported by Maslov (1956a, 1962). 
Table 2. Status of coralline red algal species described by Maslov (1935, 1936, 1950, 1955, 1956a, 1956b, 1962). , Bassi (2003); *, Bassi et al. (2005); **, Braga et al. (2005); ***, Bassi et al. (2007); §, this paper. Type material of species in group (e) has not been found. For details see the text.

\begin{tabular}{cc}
\hline Status & Species \\
\hline
\end{tabular}

(a) Species retained under original generic names

(b) New combinations

(c) Heterotypic synonyms

(d) Uncertain generic placement

(e) Type material not found
Karpathia sphaerocellulosa Maslov, 1962*

Lithophyllum duplex Maslov, 1962**

Mesophyllum schenckii var. corticesum Maslov, 1956a§

Palaeophyllum elegans Maslov, 1950*

Palaeophyllum caucasicum Maslov, 1950*

Solenophyllum paleozoicum Maslov, 1935*

Hydrolithon corculumis (Maslov) Braga et al., 2005**

Karpathia nataliae (Maslov) Bassi et al., 2005*

Solenophyllum johnsonii (Maslov) Bassi et al., 2005*

Sporolithon afonense (Maslov) Bassi et al., 2007***

Sporolithon ferganense (Maslov) Bassi et al., 2007***

Sporolithon irinae (Maslov) Bassi et al., 2007***

Sporolithon lvovicum (Maslov) Bassi et al., 2007***

Solenomeris afonensis Maslov, $1956 a^{\circ}$ (synonym of Solenomeris ogormani Douvillé, 1924)

Melobesia (Lithoporella) badjii Maslov, 1956a**

Lithothamnion caucasicum (as Lithothamnium) Maslov, 1956a§

Lithophyllum conocristatum Maslov in Krivin \& Maslov, 1962**

Lithophyllum dioscurensum Maslov, 1956a**

Lithothamnion (?) intergeminum (as Lithothamnium) Maslov, 1962a

Lithothamnion (?) iorii (as Lithothamnium) Maslov, 1956a§

Melobesia (Lithoporella) karpatica Maslov, 1962**

Palaeothamnium kossovense Maslov, $1962 \S$

Bicorium kusbassense Maslov, 1956b*

Mesophyllum kutense Maslov, 1962§

Lithophyllum (Tenarea?) lithothamnioides Maslov, 1962**

Lithothamnion microcellulosum (as Lithothamnium) Maslov, 1956a§

Lithophyllum microsporum Maslov, 1962**

Melobesia (Lithoporella) parasitica Maslov, 1956a**

Lithophyllum pavlovii Maslov, 1956a**

Lithophyllum platticarpum Maslov, 1962**

Lithothamnion praefruticulosum (as Lithothamnium) Maslov, 1956a§

Lithophyllum premoluccense var. cretacicum Maslov, 1956a**

Lithothamnion saxorum var. korolukae (as Lithothamnium) Maslov, 1956a§

Lithophyllum senonicum Maslov, 1956a**

Lithothamnion (?) suhumii (as Lithothamnium) Maslov, 1956a§

Lithothamnion tchernomoricum (as Lithothamnium) Maslov, 1956a§

Lithophyllum translucidum Maslov, 1956a**

Archaeolithothamnion rude var. asiaticum Maslov (as Archaeolithothamnium), 1936***

Lithophyllum pavlovii var. irregularis Maslov, 1956a

Lithothamnion alasanii (as Lithothamnium) Maslov, 1956a

Lithothamnion bullaense (as Lithothamnium) Maslov, 1956a

Lithothamnion microcellulosum var. junior (as Lithothamnium) Maslov, 1956a

Lithothamnion microphyllum (as Lithothamnium) Maslov, 1956a

Lithothamnion pannosum (as Lithothamnium) Maslov, 1956a

Lithothamnion taurinense var. reticulatum (as Lithothamnium) Maslov, 1956a

Lithothamnion toltraense (as Lithothamnium) Maslov, 1956a

Melobesia parasitica var. grandis Maslov, 1956a

Melobesia tarhankutica Maslov, 1962

Mesophyllum contractum Maslov, 1956a

Mesolithon lithotamnioides Maslov, 1955*

Palaeophyllum tesalii Maslov, 1950*

Solenopora concentrica Maslov, 1956a

Solenopora filiformis var. estonica Maslov, 1962

Solenopora russiensis Maslov, 1956a

Solenopora spongoides var. iuchvii Maslov, 1956a 


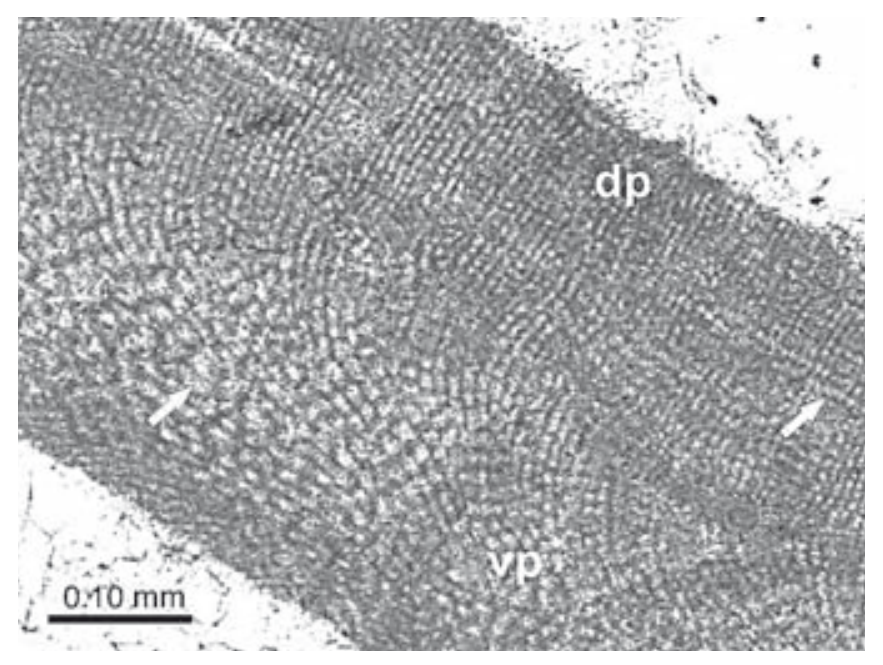

Figure 7. Lithothamnion (?) suhumii Maslov, 1956a, thin section 1964a 'Lt ? suhumii, 30, pl. 34, fig. 1'. Detail of the thick ventral core (vp) showing the possible coaxial arrangement of the filaments with cell fusions between adjacent cells (arrows). dp, dorsal portion.

\section{CONCLUDING REMARKS}

Eleven species originally ascribed to Lithothamnion (as Lithothamnium), Mesophyllum and Palaeothamnium by Maslov (1956a, 1962) are reassessed. Only the type of Mesophyllum schenckii var. corticesum Maslov, 1956a is assigned to the genus Mesophyllum Lemoine within the family Hapalidiaceae, subfamily Melobesioideae (Harvey et al., 2003a, b). The types of Lithothamnion iorii Maslov, Palaeothamnium kossovense Maslov, Mesophyllum kutense Maslov, Lithothamnion microcellulosum Maslov, Lithothamnion praefructiculosum Maslov, and Lithothamnion tchernomoricum Maslov possess: a) multiporate conceptacles, b) cell fusions (diagnostic characters of the subfamily Melobesioideae), and c) non-coaxial ventral core. As no epithallial cells are preserved in the type material, they cannot be ascribed to a definite genus within Lithothamnion-PhymatolithonClathromorphum-Synarthrophyton complex. The lack of recognizable epithallial cells is common in fossil corallines making impossible to assign many fossil melobesioid species to one of the genera in this complex.

The type specimens of 'Lithothamnium saxorum var. korolukae Maslov', 'Lithothamnion caucasicum Maslov', 'Lithothamnion (?) intergeminum Maslov', and 'Lithothamnion (?) suhumii Maslov' do not contain sufficient diagnostic characters for placement in any genus or family within Hapalidiales, Corallinales or Sporolithales in a modern context, and we have retained the original names used by Maslov for recording purposes. Their status as distinct species is impossible to assess.
In the two Maslov's monographs (1956a, 1962) and in 1950, he described a large number of coralline algal species and infra-specific taxa (67 in 1956 and 97 in 1962), establishing 41 new taxa. After our taxonomic reassessments (Bassi, 2003; Bassi et al., 2005, 2007; Braga et al., 2005, and the present study), 6 species have been retained under original generic names, 7 species have been transferred to other genera, but their status as distinct species also requires further study, 2 species have been placed in the synonymy of other species, 23 species do not contain sufficient data to allow for placement in a genus in a modern context, and we have retained the original names used by Maslov for recording purposes (Table 2). We have been unable to locate the original material of 18 other non-geniculate coralline species described by Maslov.

\section{ACKNOWLEDGEMENTS}

This study was supported by the Grupo de Investigación RNM 190 of the Junta de Andalucía (Spain) and by local research fund at the University of Ferrara (FAR). We are grateful to Vasilii Lavruschin (Geological Institute of the Russian Academy of Sciences, Moscow) for assisting during the digital photomicroscopic analysis. We are grateful to D. Basso and W.J. Woelkerling for their constructive comments on the manuscript.

\section{REFERENCES}

Adey, W.H. 1970. A revision of the Foslie crustose coralline herbarium. Det Kongelige Norske Videnskabers Selskab Skrifter, 1, 1-46.

Adey, W.H. \& Johansen, H.W. 1972. Morphology and taxonomy of Corallinaceae with special reference to Clathromorphum, Mesophyllum, and Neopolyporolithon gen. nov. (Rhodophyceae, Cryptonemiales). Phycologia, 11, 159-180.

Aguirre, J. \& Braga, J.C. 1998. Redescription of Lemoine's (1939) types of coralline algal species from Algeria. Palaeontology, 41, 489-507.

Aguirre, J., Braga, J.C. \& Piller, W.E. 1996. Reassessment of Palaeothamnium Conti, 1946 (Corallinales, Rhodophyta). Review of Palaeobotany and Palynology, 94, 1-9.

Aguirre, J., Braga, J.C., Reviers de, B. \& Woelkerling, W.J. 2012. Reassessment of Lemoine's newly discovered types of fossil corallines (Corallinales, Rhodophyta) preserved at the Muséum national d'histoire naturelle, Paris. Cryptogamie, Algologie, 33, 289-326.

Aguirre, J., Braga, J.C. \& Bassi D. 2011. Taxonomic assessment of coralline algal species (Rhodophyta; Corallinales and Sporolithales) described by Pfender, Lemoine, and Miranda from northern Spain type localities. 
Annalen des Naturhistorischen Museums in Wien, Serie A, 113, 267-289.

Bassi, D. 2003. Reassessment of Solenomeris afonensis Maslov, 1956 (Foraminifera): formerly considered a coralline red alga. Revista Española de Micropaleontologia, 35, 337-343.

Bassi, D., Zakrevskaya, E. \& Fugagnoli, A. 2002. A guide to the collections of Vladimir Maslov (Rhodophyta, Corallinales). In: Research Advances in Calcareous Algae and Microbial Carbonates (eds. Bucur, I. \& Filipescu, S.). Proceedings of the 4th I.F.A.A. Regional Meeting, Cluj-Napoca, Cluj University Press, 71-81.

Bassi, D., Braga, J.C., Zakrevskaya, E. \& Radionova, E.P. 2005. Re-assessment of the type collections of corallinalean genera (Corallinales, Rhodophyta) described by Maslov (1935-1962). Palaeontology, 48, 1-17.

Bassi, D., Braga, J.C., Zakrevskaya, E. \& Radionova, E.P. 2007. Redescription of the type collections of Maslov's species of Corallinales (Rhodophyta). II. Species included by Maslov in Archaeolithothamnium Rothpletz, 1891. Revista Española de Paleontología, 22, 115-125.

Basso, D., Fravega, P. \& Vannucci, G. 1997. The taxonomy of Lithothamnium ramosissimum (Gümbel non Reuss) Conti and Lithothamnium operculatum (Conti) Conti (Rhodophyta, Corallinaceae). Facies, 37, 167-181.

Basso, D., Fravega, P., Piazza, M. \& Vannucci, G. 1998. Revision and re-documentation of M. Airoldi's species of Mesophyllum from the Tertiary Piedmont Basin (NWItaly). Rivista Italiana di Paleontologia e Stratigrafia, 104, 85-94.

Basso, D., Rodondi, G. \& Mari, M. 2004. A comparative study between Lithothamnion minervae and the type material of Millepora fasciculata (Corallinales, Rhodophyta). Phycologia, 43, 215-223.

Bellini, A. \& Mastrorilli, V.I. 1975. Les corallinacées des coupes basales du Miocène de Bonifacio. Extraites du Bulletin de la Société des Sciences Historiques et Naturelles de la Corse, 615/616, 33-59.

Bizzozero, G. 1885. Flora Veneta Crittogamica. Parte 2. Seminario, Padova.

Bosence, D.W.J. 1983. Coralline algae from the Miocene of Malta. Palaeontology, 26, 147-173.

Braga, J.C. 2003. Application of botanical taxonomy to fossil coralline algae (Corallinales, Rhodophyta). Acta Micropaleontologica Sinica, 20, 47-56.

Braga, J.C., Bosence, D.W.J. \& Steneck, R.S. 1993. New anatomical character in fossil coralline algae and their taxonomic implications. Palaeontology, 36, 535-547.

Braga, J.C., Bassi, D., Zakrevskaya, E. \& Radionova, E.P. 2005. Reassessment of the type collections of Maslov's species of Corallinales (Rhodophyta). I. Species originally attributed to Lithophyllum and Melobesia. Revista Española de Paleontología, 20, 207-224.

Bucur, I.I. \& Filipescu, S. 1994. Middle Miocene red algae from the Transylvanian Basin (Romania). Beiträge zur Paläontologie, 19, 39-47.

Chamberlain, Y.M., Irvine, L.M. \& Walker, R. 1988. A redescription of Lithophyllum crouanii (Rhodophyta, Corallinales) in the British Isles with an assessment of its relationships to L. orbiculatum. British phycological Journal, 23, 177-192.

Conti, S. 1943. Contributo allo studio delle Corallinacee del terziario italiano. II: Le Corallinacee del Miocene del Bacino Ligure-Piemontese. Palaeontographica Italica, 4-1, 37-61.

Conti, S. 1946. Le Corallinacee del calcare miocenico (Leithakalk) del bacino di Vienna. Pubblicazioni dell'Istituto di Geologia di Genova, Serie A (Paleontologia), 1-2 (1946), 31-68.

Dieni, I., Massari, F. \& Poignant, A.F. 1979. Testimonianze di Paleocene marino in Sardegna. Rivista Italiana di Paleontologia e Stratigrafia, 85, 481-516.

Douvillé, H. 1924. Un nouveau genre d'Algues calcaires. Comptes Rendus Sommaires de la Société Géologique de France, 4, 169-170.

Fravega, P. \& Vannucci, G. 1982. Significato e caratteristiche degli episodi a rhodoliti al "top" del Serravalliano tipo. Geologica Romana, 21, 705-715.

Fravega, P., Giammarino, S. \& Vannucci, G. 1984. Episodi ad "algal balls" e loro significato al passaggio Arenarie di Serravalle-Marne di S. Agata fossili a Nord di Gavi (Bacino Terziario del Piemonte). Atti della Società Toscana di Scienze Naturali Memorie, Serie A, 91, 1-20.

Fravega, P., Piazza, M. \& Vannucci, G. 1993. Importance and significance of the rhodolithic bodies in the miocenic sequences of Tertiary Piedmont Basin. In: Studies on Fossil Benthic Algae (eds. Barattolo, F., De Castro, P. \& Parente, M.). Bollettino della Società Paleontologica Italiana, Special Volume 1, Modena, 197-210.

Gray, J.E. 1864. Handbook of British Water-Weeds or Algae. R. Hardwicke, London.

Harvey, W.H., Woelkerling, W.J. \& Wilks, K.M. 1994. The genus Synarthrophyton (Corallinaceae, Rhodophyta) in southern Australia. Phycologia, 33, 331-342.

Harvey, A.S., Woelkerling, W.J. \& Millar, A.J.K. 2003a. An account of the Hapalidiaceae (Corallinales, Rhodophyta) in south-eastern Australia. Australian Systematic Botany, 16, 647-698.

Harvey, A.S., Broadwater, S.T., Woelkerling, W.J. \& Mitrovski, P.J. 2003b. Choreonema (Corallinales, Rhodophyta): 18S rDNA phylogeny and resurrection of the Hapalidiaceae for the subfamilies Choreonematoideae, Austrolithoideae, and Melobesioideae. Journal of Phycology, 39, 988-998.

Howe, M.A. 1934. Eocene marine algae (Lithothamnieae) from the Sierra Blanca limestone. Bulletin of the Geological Society of America, 44, 507-518.

Iryu, Y., Bassi, D. \& Woelkerling, W.J. 2009. Re-assessment of the type collections of fourteen corallinalean species (Corallinales, Rhodophyta) described by W. Ishijima (1942-1960). Palaeontology, 52, 401-427.

Iryu, Y, Bassi, D. \& Woelkerling, W.J. 2012.Typification and reassessment of seventeen species of coralline red algae (Corallinales and Sporolithales, Rhodophyta) described by W. Ishijima during 1954-1978. Journal of Systematic Palaeontology, 10, 171-209.

Johnson, J.H. 1966. Tertiary red algae from Borneo. Bulletin of the British Museum (Natural History), Geological Series, 11, 255-280. 
Kaleb, S., Falace, A., Sartoni, G. \& Woelkerling, W.J. 2011. Morphology-anatomy of Mesophyllum macroblastum (Hapalidiaceae, Corallinales, Rhodophyta) in the Northern Adriatic Sea and a key to Mediterranean species of the genus. Cryptogamie, Algologie, 32, 223-242.

Krivin, A.L. \& Maslov, V.P. 1962. New data on stratigraphy and algae of Upper Cretaceous-Lower Paleocene of Marmaroshkian massif. Izvestiya Akademii nauk SSSR, Ser. Geol., 12 , 61-71 (in Russian).

Lebednik, P.A. 1977. The Corallinaceae of northwestern North America. 1 Clathromorphum Foslie emend. Adey. Syesis, 9, 59-112.

Lemoine, M.P. 1911. Structure anatomique des mélobésiées. Application à la classification. Annales de l'Institut océanographique, 2, 1-213.

Lemoine, M.P. 1928. Un nouveau genre de Mélobésiées: Mesophyllum. Bulletin de la Société botanique de France, 75, 251-254.

Lemoine, M.P. 1939. Algues calcaires fossiles de l'Algérie. Matériaux pour la Carte Géologique de l'Algérie. Ire Série Paléontologie, 9, 1-128.

Lemoine, M.P. 1977. Étude d'une collection d'algues corallinacées de la région de Skopje (Yugoslavie). Revue de Micropaléontologie, 20, 10-42.

Maslov, V.P. 1935. Some Paleozoic calcareous algae of the Southern Urals. Trudy Vsesoyusnogo Instituta Mineralnogo Syriya, 72, 3-17 (in Russian and English).

Maslov, V.P. 1936. 1. Archaeolithothamnium from Sarmatian of Kara-Tau. Trudy Geologicheskogo Instituta Akademii Nauk SSSR, 5, 119-121 (in Russian).

Maslov, V.P. 1950. Significance of red algae for the stratigraphy of USSR. Doklady Akademii Nauk SSSR, 70, 75-78 (in Russian).

Maslov, V.P. 1955. New red algal genus from the Danian of Caucasus. Doklady Akademii Nauk SSSR, 102, 827-829 (in Russian).

Maslov, V.P. 1956a. Fossil calcareous algae of USSR. Trudy Instituta geologicheskh Nauk Akademii Nauk SSSR, 160, 1-301 (in Russian).

Maslov, V.P. 1956b. New Devonian red algae from Kusbass and questions about the Corallinaceae evolution. Doklady Akademii Nauk SSSR, 110, 280-283 (in Russian).

Maslov, V.P. 1962. Fossil red algae of USSR and their connections with facies. Trudy Geologicheskogo Instituta Akademii Nauk SSSR, 53, 1-222 (in Russian).

Maslov, V.P. 1973. Atlas of Rock-Building Organisms. Izdatelstvo Nauka, Moscow (in Russian).

Mastrorilli, V.I. 1968. Nuovo contributo allo studio delle Corallinacee dell'Oligocene Ligure-Piemontese: i reperti della tavoletta Ponzone. Atti dell'Istituto di Geologia dell'Università di Genova, 5, 153-406.

Mastrorilli, V.I. 1973. Flore fossili a Corallinacee di alcune località venete tra i Berici e l'Altopiano di Asiago. Atti della Società Italiana di Scienze Naturali, Museo Civico di Storia Naturale di Milano, 114, 209-292.

McNeill, J., Barrie, F.R., Buck, W.R., Demoulin, V., Greuter, W., Hawksworth, D.L., Herendeedn, P.S., Knapp, S., Marhold, K., Prado, J., van Reine, W.F.P., Smith, G.F.,
Wiersema, J.H. \& Turland, N.J. 2012. International Code of Nomenclature for Algae, Fungi, and Plants (Melbourne Code). Koeltz Scientific Books.

Misra, P.K., Jauhri, A.K., Singh, S.K. \& Kishore, S. 2001. Coralline Algae from the Oligocene and Eocene of Kachchh, Gujarat, India. Journal of the Palaeontological Society of India, 46, 59-76.

Moussavian, E. 1993. Facies development of the Eastern Alpine Paleogene with regard to algal associations. In: Facial Development of Algae-bearing Carbonate Sequences in the Eastern Alps. Field Trip Guidebook (eds. Höfling, R., Moussavian, E. \& Piller, W.E.). International Symposium “Alpine Algae 93”, MunichVienna, B1, 1-11.

Nelson, W.A., Sutherland, J.E., Farr, T.J., Hart, D.R., Neill, K.F., Kim, H.J. \& Yoon, H.S. 2015. Multi-gene phylogenetic analyses of New Zealand coralline algae: Corallinapetra novaezelandiae gen. et sp. nov. and recognition of the Hapalidiales ord. nov. Journal of Phycology, 51, 454-468.

Peña, V., Adey, W.H., Riosmena-Rodríguez, R., Jung, M.-Y., Afonso-Carrillo, J., Choi, H.-G. \& Bárbara, I. 2011. Mesophyllum sphaericum sp. nov. (Corallinales, Rhodophyta): a new maërl-forming species from the northeast Atlantic. Journal of Phycology, 47, 911-927.

Pisera, A. 1985. Palaeoecology and lithogenesis of the Middle Miocene (Badenian) algal-vermetid reefs from the Roztocze Hills, south-eastern Poland. Acta Geologica Polonica, 35, 89-155.

Pisera, A. \& Studencki, W. 1989. Middle Miocene rhodoliths from the Korytnica Basin (Southern Poland): environmental significance and paleontology. Acta Palaeontologica Polonica, 34, 179-209.

Poignant, A.-F. 1977. The Mesozoic red algae: a general survey. In: Fossil Algae: Recent Results and Developments (ed. Flügel, E.). Springer-Verlag, Berlin, 177-189.

Poignant, A.-F. 1981. Sur des formes nouvelles d'algues rouges crétacées. Cretaceous Research, 2, 187-195.

Poignant, A.-F. \& Chaffaut, S.A. 1970. Les algues des formations transgressives maestrichtiennes, paléocènes et yprésiennes de la cote sud-orientale de la corse. Revue de Micropaléontologie, 12, 202-208.

Rasser, M.W. \& Piller, W.E. 1999. Application of neontological taxonomic concepts to Late Eocene coralline algae (Rhodophyta) of the Austrian Molasse Zone. Journal of Micropaleontology, 18, 67-80.

Segonzac, G. 1979. Algues Calcaires du Thanétien d'Espéraza (Aude) (Dasycladacées Corallinacées). Bulletin de la Société d'Histoire Naturelle de Toulouse, 115, 439-463.

Studencki, W. 1988. Red algae from the Pinczóow Limestone (Middle Miocene; Swietokrzyskie Mts., Central Poland). Acta Palaeontologica Polonica, 33, 4-57.

Vannucci, G., Quaranta, F. \& Basso, D. 2009. Historical Type Collections of Fossil Corallinales and Sporolithales (Rhodophyta) in the Dip. Te. Ris. Aracne editrice, Roma.

Vannucci, G., Quaranta, F. \& Basso, D. 2010. Revision and re-documentation of M. Airoldi's species of Lithothamnion 
from the Tertiary Piedmont Basin (NW Italy). Rivista Italiana di Paleontologia e Stratigrafia, 116, 223-235.

Woelkerling, W.J. 1983. A taxonomic reassessment of Lithothamnion Philippi (Corallinaceae, Rhodophyta) based on studies on Philippi's original collections. British phycological Journal, 18, 165-197.

Woelkerling, W.J. 1985. Proposal to conserve Lithothamnion against Lithothamnium (Rhodophyta: Corallinaceae). Taxon, 34, 302-303.

Woelkerling, W.J. 1988. The Coralline Red Algae: An Analysis of the Genera and Subfamilies of Nongeniculate Corallinaceae. Oxford University Press, Oxford.
Woelkerling, W.J. 1998. Type collections of non-geniculate corallines housed at the Laboratoire de Cryptogamie (PC). In: Non-geniculate Coralline Red Algae and the Paris Muséum: Systematics and Scientific History (eds. Woelkerling W.J. \& Lamy D.). Muséum national d'Histoire naturelle / ADAC, Paris, 279-404.

Woelkerling, W.J. \& Harvey, A. 1993. An account of southern Australia Mesophyllum (Corallinaceae, Rhodophyta). Australian Systematic Botany, 6, 571-637.

Woelkerling, W.J., Campbell, S.J. \& Harvey, A.S. 1993. Growth-forms in non-geniculate coralline red algae (Corallinales, Rhodophyta). Australian Systematic Botany, 6, 277-293. 